\section{Drug shortages hit US oncologists hard}

Bea Perks, PhD

\section{The number of drug shortages in the US has tripled between 2006 and 2012, with drug shortages now affect- ing most US oncologists and impacting on patient care. There is a need for new guidelines to control drug sub- stitutions and to single out priority populations for rela- tively scarce drugs.}

Keywords: 5FU, clinical trials, drug shortages, legislation, oncologists

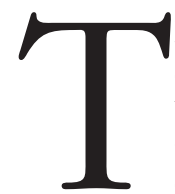

he very real threat of global drug shortages, particularly for cancer treatment [1, 2], shows little sign of abating. The impact of drug shortages on most oncologists in the US is affecting life-saving patient care, according to the findings of the largest study yet to quantify the impact of cancer drug shortages [3]. Of 250 board-certified US oncologists surveyed in late 2012 and early $2013,83 \%$ reported facing a drug shortage in the past six months, and $92 \%$ of those said their patients' treatment had been affected.

'Our results indicate that the vast majority of oncologists in the country are facing wrenching decisions about how to allocate lifesaving drugs when there aren't enough to go around,' says the study's senior author, Dr Keerthi Gogineni [4]. 'The potential impact of these drug shortages is vast: they're putting patients at risk and driving up costs of cancer care,' adds Dr Gogineni, an instructor in the Division of Hematology-Oncology in the University of Pennsylvania's Abramson Cancer Center. The results of the study were presented at the American Society of Clinical Oncology (ASCO) Annual Meeting in June 2013 [3].

The shortages recorded in this study have had the greatest impact on drugs to treat paediatric, gastrointestinal and blood cancers, depriving physicians of standard chemotherapies to prescribe across a range of cancers. It is not clear exactly how these shortages will affect patient care, but the potential risks are clear. For example, if a drug has to be substituted while treatment is already underway, there might be no established dose equivalence or known safety profile when the substitute is combined with other therapies. There is also evidence of drug shortages holding back clinical trial progression.

Drug shortages are associated with increased costs; as the availability of a drug decreases, the price of that drug, and of its substitutes, increases. The availability of a drug can decrease for several reasons as a result of manufacturing problems, or because the drug ceases to generate sufficient income for the manufacturer.

A critical production facility in the US was closed down in 2011 as a result of manufacturing and quality concerns [5]. The facility produced Johnson \& Johnson's chemotherapy drug Doxil, which is used to treat ovarian cancer, multiple myeloma and AIDS-related Kaposi's sarcoma, and a generic injectable preservative-free methotrexate, which is used to treat children with leukaemia. The threat to patients was immense, causing the US Food and Drug Administration (FDA) to step in and approve the temporary importation of Sun Pharma Global's Lipodox (pegylated liposomal doxorubicin) from India as an alternative to Doxil, and to approve APP Pharmaceutical's generic injectable preservative-free methotrexate. To achieve this, FDA collaborated with industry, patients and their families, and other stakeholders.

Gogineni et al. found that oncologists have had to substitute generics in short supply with more expensive branded drugs 60\% of the time. In the case of shortages of generic 5 fluorouracil (5FU), 22\% of physicians had to switch to the branded drug capecitabine, which costs about 140 times as much as $5 \mathrm{FU}$ for one round of colon cancer treatment.

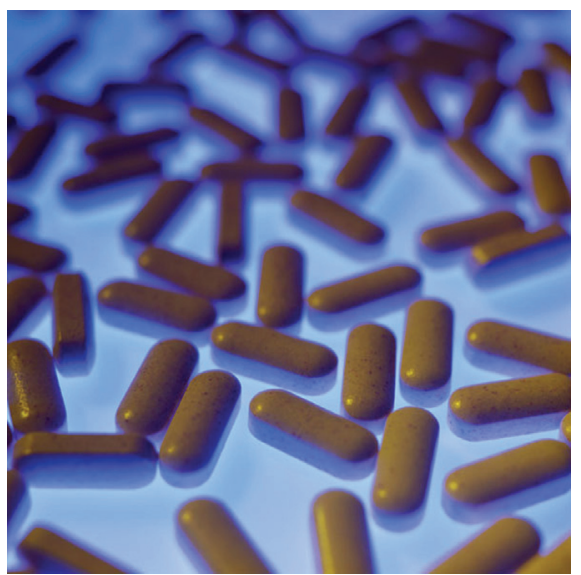

The number of drug shortages in the US tripled between 2006 and 2012 [1]. New legislation that will require manufacturers to notify FDA six months is advance of any potential shortage is being drawn up in an effort to guard against future crises. However, the law does not impose penalties on companies that fail to warn FDA, prompting the chairman of ASCO's Government Relations Committee, Dr Richard L Schilsky, to question its value. 'If there's no teeth in that legislation some companies may decide not to report as required,' he warns.

Although drug shortages affect treatments for cancer the hardest, other diseases are also affected. Drugs for attention deficit hyperactivity disorder (ADHD), for example, faced severe shortages in the US in 2012 as a result of government regulations to prevent stockpiling [6]. ADHD drugs are addictive and are apparently popular with college students, who use to then to get high or in order to get better exam results. Efforts by the US Drug Enforcement Administration to prevent this abuse have put children with ADHD at risk, according to patient groups and even FDA's own Drug Shortage Program.

Any system designed to warn regulators of impending shortages faces the hurdle of working against the interest of competing manufacturers. The Generic Pharmaceutical Association (GPhA), the US trade association for manufacturers and distributors of generic prescription drugs, recently developed an Accelerated Recovery Initiative (ARI), in response to the issue of drug shortages [7]. ARI supplies FDA with production planning and supply-chain information, but this could raise antitrust concerns if the information is shared between competing companies. For this reason, the information, services and technology company IMS Health is now an impartial third party to collect the data and provide FDA with a monthly report. The US 
Federal Trade Commission (FTC) approved ARI in August 2012, concluding that it would not be anticompetitive.

Following an executive order signed by President Obama in 2011 to address the problem of drug shortages [8], FDA reported that efforts to prevent shortages were beginning to take effect [9]. FDA Commissioner Ms Margaret Hamburg was quoted as being 'amazed and delighted' by the progress being made. According to FDA, it had prevented 128 drug shortages in the six months since the order was signed. Only 42 new drugs were reported to be in short supply in 2012, compared with 90 new shortages between January and April 2011.

Drug shortages are hampering patient care worldwide. In 2012, the results of a survey by the UK pharmacists' organization Chemist + Druggist revealed that the vast majority (95\%) of pharmacists spend more than an hour a week trying to locate out-of-stock drugs [10]. In addition, most pharmacists (93\%) regularly failed to receive drugs within 24 hours, which is the time stated in official guidance from the UK Department of Health.

The British Association of Pharmaceutical Wholesalers (BAPW), in line with the GPhA [7], has called on pharmacists and manufacturers to support objective monitoring and reporting of medicine supplies [11], although in this case the supply of brand-name drugs rather than generics. As with ARI and IMS, the need for an independent monitoring and survey service was highlighted. The BAPW noted 'inefficiencies' in the UK medicine supply chain, and has called for changes to, and enforcement of, regulation in this area.

In March 2013, Greece provided a stark reminder of the effect of national politics and financial stability on drug supplies [12]. Greece's drug regulator, the National Organization for Medicines, reported that foreign drugmakers had cut supplies to the country by $90 \%$. The shortages are reported to affect treatments for arthritis, hepatitis $\mathrm{C}$ and hypertension, cholesterol-lowering agents, antipsychotics, antibiotics, anaesthetics and immunomodulators used to treat bowel disease. The severe drug shortages have been blamed on Greek debts and a fear of parallel trade (Greece's drug prices are at least 20\% lower than the lowest prices in Europe, which is fuelling parallel trade).

Meanwhile in Canada, the country's regulatory body Health Canada has blamed a growing drug shortages problem on bulk buying [13]. According to Health Canada, bulk-buying arrangements by the Canadian
Government have caused companies to look beyond the relatively small Canadian market, sometimes leaving only one company supplying essential medicines. The danger of such an approach was brought home when the one company that supplied morphine, hydromorphone and fentanyl to the Canadian Government, Sandoz, stopped production following a fire at one of their plants. The country's Research-Based Pharmaceutical Companies (Rx\&D) and the Canadian Generic Pharmaceutical Association (CGPA) have committed up to CA $\$ 100,000$ each to address both immediate and long-term requirements to ensure that drug treatments are available when needed. The plan includes inventory tracking and the development of a system to report anticipated shortages.

While efforts to tackle drug shortages are clearly taking shape worldwide, there is considerable room for improvement. The authors of the University of Pennsylvania study revealing the harsh effects of drug shortages on US oncologists [3] highlight the pressing need for guidelines to control drug substitutions and to single out priority populations for scarce drugs.

'This is a dynamic problem, and when we learn about new shortages on the horizon, there is usually not a lot of time to plan for how to deal with them,' says Gogineni. 'Guidelines must be rapidly updated and disseminated, both to large academic medical centers and smaller community hospitals and practices'.

\section{Competing interests: None.}

Provenance and peer review: Article prepared based on extensive research, internally peer reviewed.

\section{Bea Perks, PhD, GaBI Journal Editor}

\section{References}

1. GaBI Online - Generics and Biosimilars Initiative. Drug shortages are persisting. [www.gabionline.net]. Mol, Belgium: Pro Pharma Communications International; [cited 2014 Jan 13]. Available from: www gabionline.net/Pharma-News/Drug-shortages-arepersisting

2. GaBI Online - Generics and Biosimilars Initiative. Management of drug shortages. [www.gabionline.net]. Mol, Belgium: Pro Pharma Communications International; [cited 2014 Jan 13]. Available from: www. gabionline.net/Generics/Research/Management-ofdrugs-shortages

3. Emanuel EJ, Shuman K, Chinn D, Gogineni K. Impact of oncology drug shortages. J Clin Oncol. 2013;13(Suppl; abstr CRA6510).

4. Penn Medicine, News Release. Cancer drug shortages hit 83 percent of U.S. oncologists [homepage on the
Internet]. 2013 Jun 3 [cited 2014 Jan 13]. http://www.uphs. upenn.edu/news/news_releases/2013/06/gogineni

5. GaBI Online - Generics and Biosimilars Initiative. FDA approves new suppliers to alleviate cancer drug shortages. [www.gabionline.net]. Mol, Belgium: Pro Pharma Communications International; [cited 2014 Jan 13]. Available from: www.gabionline.net/ Generics/General/FDA-approves-new-suppliers-toalleviate-cancer-drug-shortages

6. GaBI Online - Generics and Biosimilars Initiative. Shortages of ADHD drugs expected during 2012. [www.gabionline.net]. Mol, Belgium: Pro Pharma Communications International; [cited 2014 Jan 13]. Available from: www.gabionline.net/Pharma-News/ Shortages-of-ADHD-drugs-expected-during-2012

7. GaBI Online - Generics and Biosimilars Initiative. GPhA drug shortages plan gets FTC approval. [www.gabionline.net]. Mol, Belgium: Pro Pharma Communications International; [cited 2014 Jan 13]. Available from: www.gabionline.net/Pharma-News/ GPhA-drug-shortages-plan-gets-FTC-approval

8. GaBI Online - Generics and Biosimilars Initiative. Obama's fresh attempts to ease drugs shortages in the US. [www.gabionline.net]. Mol, Belgium: Pro Pharma Communications International; [cited 2014 Jan 13]. Available from: www.gabionline. net/Pharma-News/Obama-s-fresh-attempts-toease-drugs-shortages-in-the-US

9. GaBI Online-Generics and Biosimilars Initiative. FDA says efforts to prevent drug shortages are working. [www.gabionline.net]. Mol, Belgium: Pro Pharma Communications International; [cited 2014 Jan 13]. Available from: www.gabionline.net/Pharma-News/FDA-saysefforts-to-prevent-drug-shortages-are-working

10. GaBI Online - Generics and Biosimilars Initiative. UK drug shortages are far from being solved. [www. gabionline.net]. Mol, Belgium: Pro Pharma Communications International; [cited 2014 Jan 13]. Available from: www.gabionline.net/Pharma-News/UK-drugshortages-are-far-from-being-solved

11. GaBI Online - Generics and Biosimilars Initiative. Drug shortage woes continue in the UK. [www. gabionline.net]. Mol, Belgium: Pro Pharma Communications International; [cited 2014 Jan 13]. Available from: www.gabionline.net/PharmaNews/Drug-shortage-woes-continue-in-the-UK

12. GaBI Online - Generics and Biosimilars Initiative. Drugmakers accused of stopping shipments to Greece. [www.gabionline.net]. Mol, Belgium: Pro Pharma Communications International; [cited 2014 Jan 13]. Available from: www.gabionline. net/Pharma-News/Drugmakers-accused-ofstopping-shipments-to-Greece

13. GaBI Online - Generics and Biosimilars Initiative. Canada's generics and brand-name pharma come together to tackle drug shortages. [www.gabionline. net]. Mol, Belgium: Pro Pharma Communications International; [cited 2014 Jan 13]. Available from: www.gabionline.net/Pharma-News/Canada-sgenerics-and-brand-name-pharma-come-togetherto-tackle-drug-shortages

DOI: 10.5639/gabij.2014.0301.002

Copyright $\odot 2014$ Pro Pharma Communications International 